\title{
EFFECT OF PLANT BIOMASS, MANURE AND INORGANIC FERTILISER ON MAIZE YIELD IN THE CENTRAL HIGHLANDS OF KENYA
}

\author{
J. MUGWE, D. MUGENDI ${ }^{1}$, J. KUNGU ${ }^{1}$ and M. MUCHERU-MUNA ${ }^{1}$ \\ Kenya Forestry Research Institute (KEFRI). P. O. Box 20412-00200, Nairobi, Kenya \\ ${ }^{1}$ Kenyatta University (KU), School of Environmental Studies and Human Sciences, Department of \\ Environmental Sciences. P. O. Box 43844, Nairobi, Kenya
}

(Received 6 January, 2007; accepted August, 2007)

\begin{abstract}
Soil fertility degradation remains the major biophysical cause of declining per capita crop production on smallholder farms in sub-Saharan Africa. Appropriate soil fertility regimes, are therefore, critical for improved crop productivity. This study investigated the feasibility of using sole organics or their combinations with inorganic fertilisers to improve maize (Zea mays) production in the highlands central Kenya. Sole application of Calliandra calotyrsus, Leucaena trichandra trichandra, Mucuna pruriens, Crotalaria ochroleuca, Tithonia diversifolia and cattle manure at $60 \mathrm{~kg} \mathrm{~N}^{-1}$ or combined application of the organic materials (30 kg N ha-1) plus inorganic fertiliser (30 kg N ha-1) gave significantly $(P \leq 0.05)$ higher maize grain yields than the recommended rate of inorganic fertiliser $\left(60 \mathrm{~kg} \mathrm{~N} \mathrm{ha}^{-1}\right)$. These treatments maintained maize yields at 4 to $6 \mathrm{t} \mathrm{ha}^{-1}$. Farmers had their own innovations where they combined organic resources and generally appreciable yields ( 3.0 to $5.6 \mathrm{t} \mathrm{ha}^{-1}$ ) were obtained from these innovations. However, there was a maize yield gap between on station and on farm trials with on station yields having on average $65 \%$ more yields than the on-farm yields. This was mainly attributed to differences in management practices arising from partial adoption of recommended rates. There is need therefore to develop and implement mechanisms tailored to ensure that farmers' modications recommended soil amendment regimes and other agronomic practices are appropriate for enhanced crop productivity. Further studies are needed to establish the optimum mixture of different organic materials.
\end{abstract}

Key Words: Crop production, organic materials, soil fertility, Zea mays

\section{RÉSUMÉ}

La dégradation de la fertilité de sol reste la cause biophysique majeure du déclin du par capita production agricole sur les fermes de petit exploitant en Afrique au sud du Saharan. Les régimes de fertilité de sol appropriés, sont donc, critiques pour améliorer la productivité des récoltes. Cette étude a examiné la possibilité d’utiliser des organiques seuls ou leurs combinaisons avec les engrais inorganiques pour améliorer la production du maïs (Zea mays) dans les pays de montagne au centre du Kenya. L'application de Calliandra calotyrsus, Leucaena trichandra trichandra, Mucuna pruriens, Crotalaria ochroleuca, Tithonia diversifolia et le fumier de bétail à $60 \mathrm{~kg} \mathrm{~N}^{-1} \mathrm{ou}^{-1}$ application combinée des matériels organiques $\left(30 \mathrm{~kg} \mathrm{~N} \mathrm{ha}^{-1}\right)$ plus l'engrais inorganique (30 $\left.\mathrm{kg} \mathrm{N} \mathrm{ha}^{-1}\right)$ a donné significativement $(\mathrm{P} \leq 0,05)$ des hauts rendements de grain de maïs que le taux recommandé d'engrais inorganique $\left(60 \mathrm{~N} \mathrm{~kg} \mathrm{ha}^{-1}\right)$. Ces traitements ont maintenu des rendements de maïs à 4 à $6 \mathrm{t} \mathrm{ha}^{-1}$. Les fermiers ont eu leurs propres innovations où ils ont combiné des ressources organiques et des rendements généralement appréciables (3,0 à 5,6 tha ${ }^{-1}$ ) ont été obtenu de ces innovations. Cependant, il y avait une différence entre le rendement de maïs des essais sur station et sur ferme, le premier ayant en moyenne $65 \%$ plus de rendements que les rendements de sur ferme. Ceci a été principalement attribué aux différences dans les pratiques de gestion résultant de l'adoption partielle de taux recommandés. Il y a donc besoin de développer et appliquer des mécanismes adapter pour s'assurer que les modifications recommandées des régimes d'amendement de sol et les autres pratiques 
d'agronomiques par les fermiers soient appropriées pour l' amélioration de la productivité de récolte. Plus d’études sont nécessaire pour établir le mélange optimum de matériels organiques différents.

Mots Clés: La production de récolte, les matériels organiques, la fertilité de sol, Zea mays

\section{INTRODUCTION}

Soil fertility decline is increasingly viewed as a critical problem affecting agricultural productivity and environmental welfare in sub-Saharan Africa (SSA) (Bationo et al., 2004). Studies indicate the decline is a result of a combination of high rates of erosion, leaching, removal of crop residues, continuous cultivation of the land without adequate fertilisation or fallowing (Sanchez and Jama, 2002). This is aggravated by the inherent poor fertility in most tropical soils (Okalebo et al., 2003). Consequently, SSA has experienced a decrease in overall per capita food production with soil fertility being recognised as the fundamental root cause for declining food security.

In Kenya, maize (Zea mays) is a major food crop and dominates all food security considerations with a capita consumption of 103 $\mathrm{kg} \mathrm{yr}^{-1}$ (Pingali, 2001). Smallholder farmers in the central highlands of Kenya, rely on maize as the staple food crop but its production is low, estimated at 0.5 to $1.5 \mathrm{t} \mathrm{ha}^{-1} \mathrm{yr}^{-1}$ (Ouma et al., 2002). The major cause of this low yields is soil nutrient depletion indicated by negative nutrient balances. The average annual loss in soils nutrients of $42 \mathrm{~kg} \mathrm{~N}, 3 \mathrm{~kg} P$ and $29 \mathrm{~kg} \mathrm{~K} \mathrm{ha}^{-1}$ in Kenya is among the greatest in Africa (Smaling et al., 1997). Reversal of soil fertility depletion is required to increase per capita agricultural production. Use of inorganic fertilisers is one of the ways of addressing this situation but is constrained by the high costs that the resource poor farmers cannot afford. A study by Odhiambo (1994) revealed that the rising cost of inputs has resulted to many smallholder farmers reducing or abandoning the use of chemical fertiliser altogether.

Studies in the central highlands of Kenya have shown that manure is the most widely used organic fertiliser by approximately $80 \%$ of households (Kihanda, 1996). However, in the majority of farms, the available manure is not enough to fertilise the farms and the limited access to sufficient inorganic fertiliser continue to result in declining crop yields. There is therefore an urgent need to develop and promote alternative appropriate technologies that will replenish soil nutrients to enable farms to be more productive in order to meet the ever rising food demand. One of the approaches is the integrated nutrient management that combines use of organic inputs with chemical fertiliser. The beneficial effects of combined organic and inorganic sources on soil fertility, crop yields, and maintenance of soil organic matter have repeatedly been shown in field trials (Nandwa, 2003; Vanlauwe et al., 2002), yet there are no predictive guidelines for their management, such as those that exist for inorganic fertiliser. The success of combined nutrient management depends on several factors that include the types and quantities of organic materials available, and the rates and proportions at which the two nutrient sources are combined. Research in central highlands of Kenya on these issues is scanty and as such guidelines for their use and management are lacking. The objective of this study was therefore to assess the effect of applying organic materials, solely or combined with inorganic fertilisers into the soil on maize yields under both on-station and on farm conditions.

\section{MATERIALS AND METHODS}

Site description. The study was conducted in Chuka division of Meru South district of Kenya. Meru South district lies between latitudes $00^{\circ} 03^{\prime} 47^{\prime \prime} \mathrm{N}$ and $0^{\circ} 27^{\prime} 28^{\prime \prime} \mathrm{S}$ and longitudes $37^{\circ} 18^{\prime} 24^{\prime \prime} \mathrm{E}$ and $28^{\circ} 19^{\prime} 12^{\prime \prime} \mathrm{E}$. It covers an area of $1032.9 \mathrm{~km}^{2}$ and Chuka division covers an area of $169.6 \mathrm{~km}^{2}$. According to agro-ecological conditions (based on temperature and moisture supply), the area lies in the Upper Midland Zone (UM2-UM3) (Jaetzold and Schmidt, 1983) on the eastern slopes of Mt. Kenya at an altitude of 1500 
$m$ above sea level with an annual mean temperature of $20^{\circ} \mathrm{C}$ and a total annual rainfall of $1200-1400 \mathrm{~mm}$. The rainfall is received in two seasons; the long rains (LR) lasting from March through June, and short rains (SR) from October through December. The soils are mainly humic Nitisols (Jaetzold and Schmidt, 1983), which are deep, well weathered with moderate to high inherent fertility. The district is a predominately maize growing zone with small land sizes ranging from 0.1 to 2 ha with an average of 1.2 ha per household.

The area is characterised by rapid population growth, low agricultural productivity, increasing demands on agricultural resources and low soil fertiltiy (Gok, 2001). The main cash crops are coffee (Coffea Arabica L.) and tea Camelina sinensi (L) O. Kuntze) while the main staple food crop is maize (Zea mays L.), which is cultivated from season to season mostly intercropped with beans (Phaseolus vulgaris L). Other food crops include potatoes (Ipomea batatas (L.) Lam), banans (Musa spp. L.) and vegetables that are mainly grown for subsistence consumption. Livestock production is a major enterprise especially dairy cattle that is of improved breeds. Other livestock in the area include sheep, goats and poultry.
The rainfall trends during the study period are shown in Figure 1. The total rainfall received in $2002 \mathrm{LR}$ and SR was $858.1 \mathrm{~mm}$ and $790.1 \mathrm{~mm}$, respectively while in $2003 \mathrm{LR}$ and SR a total of 840.1 and $241.4 \mathrm{~mm}$ was recorded, respectively. The rainfall peaks coincided with the months of April and November during the study period, a rainfall pattern expected for this area.

On-station experiment. An on-station experiment was established in March 2000 in Kirege School in Chuka divisions, Meru South district. The trial had 14 treatments comprising of six organic resources applied solely or combined with inorganic fertiliser, sole inorganic fertiliser and a control. The organic resources were two herbaceous legumes; Mucuna pruriens and Crotalaria ochloleuca (intercropped with maize), two leguminous shrubs; Calliandra calothyrsus, Leucaena trichandra (biomass transfer), cattle manure and Tithonia diversifolia (biomass transfer) (Table 1). The experiment was a randomised complete block design with three replications. Maize (Zea mays L, var. H513) was the test crop. Plot sizes measured $6 \mathrm{~m} \mathrm{x} 4.5$, and maize was planted at a spacing of $0.75 \mathrm{~m}$ and 0.5 $\mathrm{m}$ inter and intra-row spacing, respectively. Fertiliser $\mathrm{N}$ was applied in split applications with 
TABLE 1. Treatments as the on-station experiment at Chuka, Meru South district, Kenya

\begin{tabular}{lcc}
\hline Treatment & \multicolumn{2}{c}{ Amount of N supplied $\left(\mathrm{kg} \mathrm{ha}^{-1}\right)$} \\
\cline { 2 - 3 } & Organic & Inorganic \\
\cline { 2 - 3 } Mucuna pruriens alone & $*$ & 0 \\
Mucuna + 30 kg N ha-1 & $*$ & 30 \\
Crotalaria ochroleuca alone & $*$ & 0 \\
Crotalaria + 30 kg N ha-1 & $*$ & 30 \\
Cattle manure alone & 60 & 0 \\
Cattle manure + 30 kg N ha-1 & 30 & 30 \\
Tithonia diversifolia & 60 & 0 \\
Tithonia + 30 kg N ha-1 & 30 & 30 \\
Calliandra calothrysus & 60 & 0 \\
Calliandra + 30 kg N ha-1 & 30 & 30 \\
Leucaena trichandra & 60 & 0 \\
Leucaena + 30 kg N ha-1 & 30 & 30 \\
Recommended rate of fertiliser & 0 & 60 \\
Control (no inputs) & 0 & 0 \\
\hline
\end{tabular}

*Total $\mathrm{N}$ applied varied among seasons and depended on amount of biomass produced during the previous season (see Table 2)

33.3\% being top-dressed 4 weeks after planting and the rest (66.6\%) 4 weeks later. A uniform P application was done in all the plots at the recommended rate (60 $\mathrm{kg} \mathrm{P} \mathrm{ha}^{-1}$ ) as triple super phosphate (TSP). Other agronomic procedures for maize production were approximately followed after planting.

The herbaceous legumes (Mucuna sp. and Crotalaria sp.) were intercropped between two maize rows one week after planting maize. After maize was harvested, these legumes were left to grow in the field until land preparation for the subsequent season when they were harvested, weighed, chopped and incorporated into the soil to a depth of $15 \mathrm{~cm}$. The weight of the herbaceous legume biomass applied during the study period varied across the seasons (Table 2). The amount of $\mathrm{N}$ contributed into the soil via the incorporated biomass was calculated by multiplying amount of biomass $(\mathrm{kg})$ with the $\mathrm{N}$ concentration in the biomass (\%). The quantity of herbaceous legumes produced and their $\mathrm{N}$ contribution into the soil are shown in Table 2.

The other organic materials (calliandra, leucaena, tithonia and cattle manure) were incorporated into the soil to a depth of $15 \mathrm{~cm}$ during land preparation. Sub samples of all organic materials were collected uniformly at the beginning of each season and analysed. The samples were first washed with distilled water and oven dried at $65^{\circ} \mathrm{C}$ for 48 hours. Samples were ground, packed in polythene bags, and stored under dry conditions. The dry plant samples were analysed at the International Centre for Research in Agroforestry (ICRAF) laboratory. Total N, P, K, Ca and Mg was analysed by Kjedahl digestion with concentrated sulphuric acid (Anderson and Ingram, 1993). Nitrogen and phosphorus were determined colorimetrically while potassium was by flame photometry (Parkinson and Allen, 1975; Okalebo et al., 2002). Magnesium and calcium was by atomic absorption spectrophotometer (Anderson and Ingram, 1993). Table 3 shows the mean nutrient composition of the organic materials used during the four seasons under study.

TABLE 2. Amount of herbaceous legumes produced and their $N$ contribution into the soil during $2002 \mathrm{LR}$ to $2003 \mathrm{SR}$ at Chuka, Meru South district, Kenya

\begin{tabular}{|c|c|c|c|c|c|c|}
\hline \multirow[t]{2}{*}{ Treatment } & \multirow[t]{2}{*}{2002 LR } & 2002 SR & 2003 LR & 2003 SR & \multirow[t]{2}{*}{ Average } & \multirow[t]{2}{*}{ Mean N } \\
\hline & & $-\quad-$ Bio & in $\mathrm{tha}^{-1} \mathrm{se}$ & -1 & & \\
\hline Mucuna & 1.7 & 2.8 & 0.8 & 0.2 & 1.38 & 34.4 \\
\hline Mucuna + 30 kg ha-1 & 1.9 & 3.2 & 0.9 & 0.3 & 1.60 & 40.0 \\
\hline Crotalaria & 2.3 & 2.3 & 0.6 & 0.2 & 1.36 & 36.7 \\
\hline Crotalaria + $30 \mathrm{~kg} \mathrm{ha}^{-1}$ & 2.8 & 2.5 & 0.8 & 0.3 & 1.59 & 42.9 \\
\hline SED & 0.19 & 0.17 & 0.11 & 0.11 & 0.08 & 2.1 \\
\hline
\end{tabular}

SED $=$ Standard error of difference between means 
TABLE 3. Average nutrient compositon (\%) of organic materials applied in the soil during the study period at Chuka, Meru South District, Kenya

\begin{tabular}{lllllll}
\hline Treatment & $\mathrm{N}$ & $\mathrm{P}$ & $\mathrm{Ca}$ & $\mathrm{Mg}$ & $\mathrm{K}$ & Ash \\
\hline Cattle manure & 1.3 & 0.2 & 1.0 & 0.4 & 1.8 & 45.9 \\
Tithonia & 3.2 & 0.2 & 2.1 & 0.6 & 3.0 & 13.0 \\
Calliandra & 3.3 & 0.2 & 1.0 & 0.4 & 1.2 & 5.9 \\
Leucaena & 3.6 & 0.2 & 1.4 & 0.4 & 1.8 & 8.5 \\
SED & & & & & & 0.05 \\
\hline
\end{tabular}

SED $=$ Standard error of differences between means

Maize grain and stover were harvested at maturity from a net plot of $21.0 \mathrm{~m}^{2}$ after leaving one row on each side of the plot and the first and last maize plants on each row to minimize the edges effect. Maize cobs were manually separated from the stover, sun-dried, and packed in paper bags before threshing. After threshing, moisture content of the grains was determined using a moisture meter and grain weights adjusted to $12.5 \%$ moisture content.

On farm trials. Researcher designed and farmer managed on farm trials, classified as 'Type 2' according to Franzel et al. (2002), were established during 2002 LR. The aim was to assess performance of the different soil fertility replenishment technologies, tested at the on station experiment, under a variety of farmers' conditions. High variability in management among farmers is known to sometimes mask treatment performance and control of some factors is recommended for purposes of providing appropriate biophysical data (Musaers et al., 1997). In these Type 2 trials, variability as controlled by ensuring that all farmers participating in the trial used the same maize variety and inorganic fertiliser. The farmers were therefore provided with maize seed, Hybrid 513 (H513) and compound fertiliser, nitrophosphate (NPK; 23:23:0). After planting the farmers carried out all the necessary agronomic practices independently.

During the growing season farmers were visited and technologies they were testing assessed, plots for each of the treatments measured and marked, and a clear record made on the technologies each farmer was testing. These, according to Fanzel et al. (2002) were classified as Type 3 on farm trials. The farmers were also requested to avoid harvesting the crop until crop maturity. At crop maturity the researcher visited the farmers and organized the harvesting and data taking. During harvesting a representative net plot of 3 x 3 m was marked and maize yields taken.

Soil characterisation. Before planting the experiments (both on-station and on-farm) soil characterization was carried out. At the onstation, soil was sampled in March 2000 at 0-15 $\mathrm{cm}$ depth. On the farms, soils were also sampled at $0-15 \mathrm{~cm}$ depth from 31 farms. Samples were taken from the cropland, which farmers demarcated as their main cropland where they mainly planted maize. The samples were analyzed for, $\mathrm{pH}$, exchangeable magnesium (Mg), calcium (ca), potassium (K), available phosphorus $(\mathrm{P})$, total organic carbon $(\mathrm{C}$, and total nitrogen $(\mathrm{N})$. All the analyses were carried out at the International Centre for Research in Agroforestry (ICRAF) laboratories using procedure outlined in the ICRAF laboratory manual (ICRAF, 1995). At the on-station experiment, results showed that $\mathrm{pH}$ of the soil was 5.2 Total $\mathrm{N}$ and C was $0.21 \%$ and $1.8 \%$, respectively. Available P was $7.1 \mathrm{Cmol}$ $\mathrm{kg}^{-1}$, K was $0.3 \mathrm{Cmol} \mathrm{kg}{ }^{-1}$, Ca was $3.4 \mathrm{Cmo} \mathrm{kg}^{-1}$, and $\mathrm{Mg}$ was $\mathrm{Cmol} \mathrm{kg}{ }^{-1}$.

On the farms the $\mathrm{pH}$ ranged from 4.1 to 6.0 with a mean of 4.8 , indicating that soils in the smallholder farms in this study were acidic. Total $\mathrm{C}$ and $\mathrm{N}$ were found to be low in most farms ranging from 1.45 to $2.26 \%$ and $0.05 \%$ to $0.25 \%$, 
respectively. The mean $\mathrm{C}$ content was $1.73 \%$ while the mean $\mathrm{N}$ content was $0.16 \%$. Available phosphorus was found to be low, ranging from 1.3 to $15.8 \mathrm{ppm}$ with more than $70 \%$ of the farms being critically deficient in P. Only 2 farms (6\%) has $\mathrm{P}$ in the adequate range of 13 to $22 \mathrm{ppm}$ due to possibly user of some forms of manure or inorganic $\mathrm{P}$ fertiliser additions.

Statistical analysis. Capturing and exploration of all data was carried out in excel spread sheet while statistical analysis was performed using Genstat 5 for windows (Release 8.1) computer package (Genstat, 2005). After testing for normality the data were subjected to Analysis of Variance (ANOVA) that was used to test for significant differences among treatments.

Differences between treatment means were declared significant at $\mathrm{P} \leq 0.05$ and treatment means found to be significantly different were separated by Least Significant Differences (LSD) at $\mathrm{P} \leq 0.05$. Single degree of freedom contrasts were performed to compare maize yields from organic resources and inorganic fertiliser treatments. Due to unbalanced nature of the experiments at the farmers' fields, regression modelling using Genstat programme was used to analyze differences in mean yields (Stern et al., 2004). This yielded predicted means that each had an estimated standard error (SE) but the average (LSD) or standard error of differences (SED) at $\alpha=0.05$ was used to compare the means. To determine differences in yields viability between on-station and on-farm experiments, coefficient of variation (CV), which is a mesure of scatteredness of data (Stern et al., 2004) was used.

\section{RESULTS}

On-station experiment. Maize grain yields were significantly affected by the treatments $(\mathrm{P}=0.05)$. All treatments recorded significantly higher maize yields than the control treatment in all seasons (Table 4). Overall mean maize grain yields over the four seasons were highest, (greater than $5.0 \mathrm{t}$

TABLE 4. Maize grain yields from on-station on trial under different soil fertility replenishment inputs during 2002 LR to 2003 SR at Chuka, Meru South district, Kenya

\begin{tabular}{|c|c|c|c|c|c|c|}
\hline Treatment & Treatment & 2002 LR & 2002 SR & 2003 LR & $03 \mathrm{SR}$ & Mean \\
\hline 1 & Mucuna pruriens & 2.5 & 4.6 & 3.0 & 1.5 & 2.9 \\
\hline 2 & Mucuna + 30 kg N ha-1 & 3.1 & 5.5 & 4.2 & 2.1 & 3.7 \\
\hline 3 & Crotalaria ochroleuca & 3.3 & 5.3 & 4.1 & 1.9 & 3.6 \\
\hline 4 & Crotalaria + 30 kg N ha-1 & 4.1 & 6.1 & 4.8 & 3.3 & 4.6 \\
\hline 5 & Cattle manure & 3.0 & 6.1 & 5.0 & 2.3 & 4.1 \\
\hline 6 & Cattle Manure $+30 \mathrm{~kg} \mathrm{~N} \mathrm{ha}^{-1}$ & 4.6 & 5.3 & 5.6 & 3.5 & 4.8 \\
\hline 7 & Tithonia diversifolia & 4.9 & 7.9 & 7.3 & 3.9 & 6.0 \\
\hline 8 & Tithonia + 30 kg N ha-1 & 4.0 & 7.6 & 7.1 & 4.5 & 5.8 \\
\hline 9 & Calliandra calothrysus & 3.9 & 6.5 & 6.4 & 4.3 & 5.3 \\
\hline 10 & Calliandra + 30 kg N ha-1 & 5.0 & 8.0 & 6.5 & 4.8 & 6.1 \\
\hline 11 & Leucaena trichandra & 3.8 & 7.5 & 6.6 & 3.5 & 5.3 \\
\hline 12 & Leucaena + 30 kg N ha-1 & 4.1 & 7.2 & 6.1 & 3.9 & 5.3 \\
\hline 13 & Fertiliser (60 kg N ha ${ }^{-1}$ ) & 3.5 & 5.8 & 5.3 & 2.0 & 4.2 \\
\hline 14 & Control (no inputs) & 1.3 & 2.6 & 2.4 & 0.6 & 1.7 \\
\hline$P$ & & 0.002 & 0.001 & $<0.001$ & $<0.001$ & 0.001 \\
\hline SED & & 0.4 & 0.5 & 0.5 & 0.4 & 0.6 \\
\hline
\end{tabular}

SED $=$ Standard error of differences between means 
$\mathrm{ha}^{-1}$ ) in treatments where Tithonia, Calliandra and Leucaena alone or in combination with $30 \mathrm{~kg}$ $\mathrm{N} \mathrm{ha}^{-1}$ from inorganic fertiliser were applied. Also, the overall mean maize grain yields were higher in $2002 \mathrm{SR}$ and $2003 \mathrm{LR}$ with $6.1 \mathrm{t} \mathrm{ha}^{-1}$ and $5.0 \mathrm{t}$ ha $^{-1}$, respectively, than in 2002 LR and 2003 SR with $3.7 \mathrm{t} \mathrm{ha}^{-1}$ and $3.0 \mathrm{t} \mathrm{ha}^{-1}$, respectively.

In 2002 SR and 2003 LR, treatments that had Tithonia, Calliandra and Leucaena prunings alone or with combination with inorganic $\mathrm{N}$ fertiliser applied recorded yields of more than 6.2 $\mathrm{t} \mathrm{ha}^{-1}$ (Table 4). In $2002 \mathrm{LR}$, maize grain yield ranged from $1.3 \mathrm{t} \mathrm{ha}^{-1}$ (control treatment) to $5.0 \mathrm{t}$ ha $^{-1}$ (cattle manure $+30 \mathrm{~kg} \mathrm{~N} \mathrm{ha}^{-1}$ ). During this season, all the treatments except Mucuna alone, Mucuna $+30 \mathrm{Kg} \mathrm{N} \mathrm{ha}^{-1}$, Crotalaria alone and the control treatments, recorded maize grain yields that were more than $4.0 \mathrm{t} \mathrm{ha}^{-1}$.

Maize grain yields during 2003 SR were the lowest among the four seasons under study, and ranged from $0.6 \mathrm{t} \mathrm{ha}^{-1}$ (control) to $4.8 \mathrm{t} \mathrm{ha}^{-1}$ $\left(\right.$ Tithonia $+30 \mathrm{~kg} \mathrm{~N} \mathrm{ha}^{-1}$ ) (Table 4). The low yields were probably due to low rainfall amount received during 2003 SR compared to 2002 LR and 2002 SR (Fig. 1). Herbaceous legumes generally recorded low maize yields ranging from 1.5 to $4.2 \mathrm{t} \mathrm{ha}^{-1}$ except in 2002 SR. However, supplementation with $30 \mathrm{~kg} \mathrm{~N} \mathrm{ha}^{-1}$ increased maize yields slightly.

Contrasts performed to compare maize grain yields obtained from treatments that had sole organic materials applied with the inorganic fertiliser only treatment, i.e., treatments $1,2,5,7$, 8, 9 and 13, showed that in all seasons, maize grain yields obtained from sole application of Tithonia and Leucaena were significantly higher than from the inorganic fertiliser treatment (Table 5). During 2003 LR, maize yields from treatments that had sole application of Tithonia, Calliandra and Leucaena were more than 95\% higher than the inorganic fertiliser treatment, while during 2003 SR treatments with Calliandra and Leucaena recorded particularly high maize yields of $125 \%$ and $116 \%$ beyond the fertiliser treatment, respectively (Table 5). Contrasts comparing maize yields from treatments that had combined application of organic materials plus inorganic

TABLE 5. Percentage yield change from contrasts comparing sole organic material treatments with fertiliser alone treatment and organic plus fertiliser, versus fertiliser treatment at Chuka, Meru South district, Kenya

\begin{tabular}{|c|c|c|c|c|}
\hline Contrast & 2002 LR & 2002 SR & 2003 LR & 2003 SR \\
\hline $\begin{array}{l}\text { Sole organics vs } \\
\text { Inorganic fertiliser }\end{array}$ & -- & $\%$ increas & crease (-) & -- \\
\hline
\end{tabular}

\begin{tabular}{lllll}
\hline 1 vs 13 & -21 & -28 & $-43^{\star \star}$ & -23 \\
2 vs 13 & -5 & -11 & -21 & 3 \\
5 vs 13 & 6 & -14 & -5 & 15 \\
7 vs 13 & $35^{\star}$ & $41^{*}$ & $37^{*}$ & $96^{*}$ \\
8 vs 13 & $31^{*}$ & 15 & $33^{\star}$ & $125^{\star \star}$ \\
9 vs 13 & 13 & 12 & 20 & $116^{\star \star}$
\end{tabular}

\section{Organics + feriliser vs inorganic fertiliser}

\begin{tabular}{lllll}
3 vs 13 & -7 & -21 & $-23^{\star}$ & -6 \\
4 vs 13 & 16 & -5 & -10 & $67^{*}$ \\
6 vs 13 & $32^{\star}$ & -9 & 5 & $76^{\star}$ \\
10 vs 13 & $41^{\star}$ & $37^{\star}$ & $23^{\star}$ & $141^{\star \star \star}$ \\
11 vs 13 & 8 & $28^{\star}$ & $24^{*}$ & $73^{\star \star \star}$ \\
12 vs 13 & 17 & $25^{\star}$ & 15 & $94^{\star \star \star}$ \\
\hline
\end{tabular}

* * * Significant at $P=0.05$ and $P=0.01$, respectively

$1=$ Mucuna alone, $2=$ Crotalaria alone $+30 \mathrm{~kg} \mathrm{~N} \mathrm{ha}^{-1}, 5=$ manure alone, $7=$ Tithonia alone, $8=$ Calliandra alone, $9=$ Leucaena alone, 13 - fertiliser @ $60 \mathrm{~kg} \mathrm{Nha}^{-1}$ 
fertiliser with inorganic feriliser alone showed that combined application of organic materials with fertiliser recorded higher maize yields than sole inorganic fertiliser treatment in most seasons (Table 5).

On-farm experiments. Maize yields from the onfarm trials varied significantly among the treatments and the seasons (Tables 6 and 7). In the Type 2 trial, maize yields were significantly higher in cattle manure alone and cattle manure + $30 \mathrm{~kg} \mathrm{~N} \mathrm{ha}^{-1}$ than in other treatments during 2002 LR. Overall mean maize yields were higher in 2002 SR than 2002 LR with an overall mean of 3.8 $\mathrm{t} \mathrm{ha}^{-1}$ and $2.1 \mathrm{t} \mathrm{ha}^{-1}$, respectively. Generally, lowest yields in Type 2 trials were obtained from herbaceous legumes and the control treatments, while manure, Tithonia, Calliandra and Leucaena gave the highest yields in most seasons.

In the Type 3 trials, highest maize yields during 2002 LR season were obtained from inorganic fertiliser, Calliandra, cattle manure alone and cattle manure $+30 \mathrm{~kg} \mathrm{~N} \mathrm{ha}^{-1}$ (Table 7). In 2002 SR, highest maize yields were obtained from Tithonia $+30 \mathrm{~kg} \mathrm{~N} \mathrm{ha}^{-1}$. In $2003 \mathrm{SR}$, highest yields were recorded in cattle manure $+30 \mathrm{~kg} \mathrm{~N}$ $\mathrm{ha}^{-1}$. In $2003 \mathrm{SR}$, highest yields were recorded in cattle manure $+30 \mathrm{~kg} \mathrm{~N} \mathrm{ha}^{-1}$, Calliandra $+30 \mathrm{~kg}$ $\mathrm{N}$ ha $^{-1}$ in Type 2 trials. Except for herbaceous legumes, all organic materials alone or in combination with inorganic fertiliser gave reasonable yields of more than $3.5 \mathrm{t} \mathrm{ha}^{-1}$ in most seasons. Generally, the effect of combining organic materials with inorganic fertiliser on maize yields in the on-farm trials had no definite trend possibly because of the variability among fields especially in Type 3 trials. However, crotalaria, cattle manure, Tithonia, Calliandra and Leucaena in combination with fertiliser showed improved maize performance. These results also generally showed a similar trend to that of onstation trial, where cattle manure, Tithonia, Calliandra and Leucaena sole application

TABLE 6. Maize grain yields from "Type 2" on farm trial during 2002 LR to 2003 SR under different soil management practices at Chuka, Meru South district, Kenya

\begin{tabular}{lcccc}
\hline Treatment & 2002 LR & 2002 SR & 2003 LR & 2003 SR \\
\hline Mucuna pruriens alone & 1.6 & 2.7 & 1.6 & 2.3 \\
Mucuna = 30 kg N ha-1 & 1.2 & 1.4 & nd & 3.2 \\
Crotalaria ochloreuca alone & 0.4 & 2.5 & 1.0 & 1.6 \\
Crotalaria_30 kg N ha-1 & 3.3 & 4.5 & 2.8 & 3.3 \\
Cattle manure & 3.8 & 4.2 & 4.2 & 2.6 \\
Cattle manure + 30 kg N ha-1 & 4.2 & 4.8 & 4.7 & 5.3 \\
Tithonia diversifolia alone & 1.3 & 2.4 & 2.4 & 5.0 \\
Tithonia + 30 kg N ha-1 & 2.8 & 3.4 & 3.7 & 3.2 \\
Calliandra clothyrsys alone & 3.2 & 4.1 & 2.2 & 3.4 \\
Calliandra + 30 kg N ha-1 & 1.7 & 4.4 & 4.0 & 4.3 \\
Leucaena trichandra alone $_{\text {Leucaena + 30 kg N ha' }}^{-1}$ & 1.8 & 4.7 & 2.1 & 1.9 \\
Recommended rate of fertiliser (60 kg N ha-1) & 2.1 & 4.2 & 3.3 & 3.9 \\
Control & 3.0 & 3.9 & 3.2 & 3.2 \\
& 1.1 & 1.4 & 1.2 & 1.2 \\
Coefficient of variation (CV) & & & & \\
SED & $23 \%$ & 0.001 & 0.032 & 0.001 \\
\hline
\end{tabular}

SED $=$ Standard error of differences between means $\mathrm{nd}=$ not determined 
TABLE 7. Maize rain yields $\left(\mathrm{t} \mathrm{ha}^{-1}\right)$ from "Type 3 " on farm trial during $2002 \mathrm{LT}$ to $2003 \mathrm{SR}$ under different soil management practices in Chuka, Meru South District, Kenya

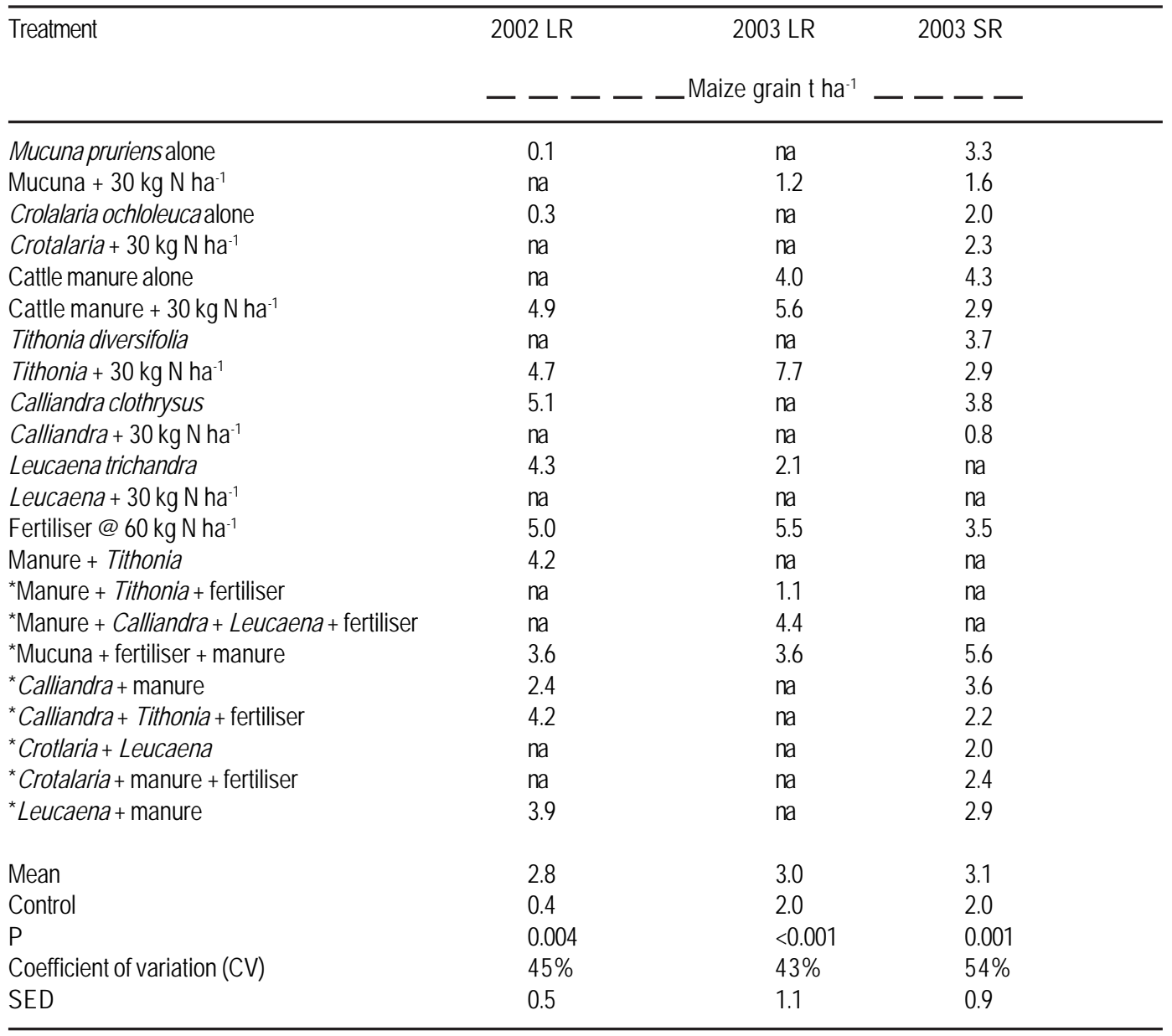

na $=$ treatment was not present on at least three farms

* = Farmers' modifications

SED $=$ Standard error of differences between means

resulted into the highest yields, while herbaceous legumes and the control treatments gave the lowest.

In Type 3 trials, farmers had innovations in the use of the inputs where they mixed different organic materials. During 2002 LR, farmers had four innovations, while during 2003 SR, they had seven, recording an increase in modification of technologies/treatments (Table 7). Maize yields during 2002 LR for these innovations ranged from 2.4 to $4.3 \mathrm{t} \mathrm{ha}^{-1}$ compared to $0.4 \mathrm{t} \mathrm{ha}^{-1}$ from the control treatment. During 2003 SR and LR, yields from the modified treatments ranged from 2.0 to $5.5 \mathrm{t} \mathrm{ha}^{-1}$ against the control treatment that had 2.0 t ha $^{-1}$.

The yields from the farms were observed to be highly variable among the treatments and farmers. The Type 3 trials had higher variability than Type 2 trials. For example, in 2003 LR coefficient of variation (CV) for Type 2 trials was 27\% while that of Type 3 trial was 43\%. In 2003 SR, CV for Type 2 trials was 32\% while that of Type 3 was 54\% (Tables 6 and 7). 
TABLE 8. Comparisons of overall maize yield ( $\left(\mathrm{ha}^{-1}\right)$ over 4 seasons from on station and Type 2 on farm trials in Meru South District, Kenya

\begin{tabular}{|c|c|c|c|c|}
\hline Treatment & On station & Type 2 on farm trial & $\%$ difference & t-test P- value \\
\hline Mucuna pruriens & 2.9 & 2.1 & 3.8 & $0.056^{*}$ \\
\hline Mucuna + 30 kg N ha-1 & 3.7 & 2.0 & 85 & $0.01^{*}$ \\
\hline Crotalaria ochloreuca & 3.6 & 1.4 & 157 & $0.002^{*}$ \\
\hline Crotalaria + 30 kg N ha-1 & 3.6 & 1.4 & 157 & $0.045^{\star}$ \\
\hline Cattle manure & 4.4 & 3.3 & 33 & $0.04^{*}$ \\
\hline Cattle manure + $30 \mathrm{~kg} \mathrm{~N} \mathrm{ha}^{-1}$ & 4.8 & 4.8 & 0 & $0.89 \mathrm{~ns}$ \\
\hline Tithonia diversifolia & 6.0 & 2.8 & 114 & $0.001^{*}$ \\
\hline Tithonia + 30 kg N ha-1 & 5.8 & 5.3 & 9 & $0.67 \mathrm{~ns}$ \\
\hline Calliandra calothyrsus & & 5.3 & 3.2 & $660.01^{*}$ \\
\hline Calliandra + 30 kg N ha-1 & 6.0 & 3.6 & 67 & $0.005^{\star}$ \\
\hline Leucaena trichandra & 5.3 & 2.6 & 104 & $0.006^{*}$ \\
\hline Leucaena + 30 kg N ha-1 & 5.5 & 3.3 & 67 & $0.02^{*}$ \\
\hline Recommended rate of fertiliser $\left(60 \mathrm{~kg} \mathrm{~N} \mathrm{ha}^{-1}\right)$ & 4.0 & 3.3 & 21 & $0.53 \mathrm{~ns}$ \\
\hline
\end{tabular}

* = significant at $p=0.05$

A comparison of maize yields from similar treatments in on-station and Type 2 on-farm trials revealed a yield gap. Most treatments gave higher yields from the on station experiment than from the on farm trials (Table 8). On average, on station yields were $65 \%$ higher than the on farm yields and in some treatments such as Crotalaria, on-station yields were $157 \%$ higher than the onfarm yields.

\section{DISCUSSIONS}

The consistently higher maize yields recorded in treatments where Tithonia, Callinadra and Leucaena prunings either alone or in combination with fertiliser was applied was attributed to higher amounts of nutrients than all the other treatments, mainly nitrogen that was availed by these inputs for maize growth. The lower maize yield in manure treatments in comparison to those of Tithonia, Calliandra and Leucaena could be attributed to lower rates of manure decomposition and therefore slow rate of availing nutrients to the maize crop. Though the amount of $\mathrm{N}$ added via all these organic materials was the same $(60 \mathrm{~kg} \mathrm{~N}$ $\mathrm{ha}^{-1}$ ), cattle manure contained lower nitrogen concentration than all the others (Table 2) and could have released the $\mathrm{N}$ slower due to higher $\mathrm{C}: \mathrm{N}$ ratio compared to the other organic materials
(Cadisch et al., 1998; Kimani et al., 2004) therefore affecting maize growth.

Several studies have shown large maize yields responses with application of Tithonia, Calliandra and Leucaena biomass. For example, in Western Kenya, yield increase of up-to 200\% was reported following application of Tithonia biomass (Gachengo et al., 1999), while in central Kenya increases in maize with application of Tithonia, Calliandra and Leucaena biomass has been reported (Mugendi et al., 1999; Gachimbi et al., 2004; Kimetu et al., 2004). Studies from other parts of Africa have also reported increased maize yields following application of Tithonia biomass (Ganunga et al., 1998; Jiri and Waddington, 1998). The large response in increasing maize yields upon application of these organic materials into the soil is attributed to the fact that they contain high amounts of nutrients especially $\mathrm{N}$, as well as other nutrients such as phosphorus $(\mathrm{P})$, potassium (K), and magnesium (Mg) and may thus, prevent micronutrient deficiencies (Murwira et al., 2002).

The exceptionally high yields recorded in 2002 SR and 2003 LR could be attributed to the good rainfall distribution during these two seasons (Fig. 1) and also probably due to nutrient accumulation over the seasons since the experiment was set up in 2000. Similarly, the large 
difference between yields from Tithonia, Leucaena and Calliandra plus fertiliser treatments and that of fertiliser alone treatment during 2003 SR could also be attributed to the same nutrient accumulation in organic materials treatments. Other studies have reported nutrient accumulation as a result of applying organic materials over several seasons resulting in increased yields (Goyal et al., 1992). This is because organic materials, e.g., Calliandra and Leucaena have tannin and lignin content, which slow their decomposition (Tian et al., 1993) and therefore has a long-term effect on nutrient availability.

The higher yields from organic materials plus inorganic fertiliser treatments than sole inorganic fertiliser treatment is an indication that integrated use or organic and inorganic nutrient sources of $\mathrm{N}$ is advantageous over the use or inorganic fertiliser alone. Earlier studies demonstrated that use of organics could enhance efficiency of chemical fertiliser (Dudal and Roy, 1995). Other researchers have observed higher maize yields through application of high quality organic inputs such as Tithonia in combination with inorganic fertiliser as compared to sole application of inorganic fertilisers (Okoko et al., 2003; Esilaba et al., 2005). Integration of inorganic and organic nutrient inputs could therefore be considered as a better option in increasing fertiliser use efficiency and providing a more balanced supply of nutrients. Vanlauwe et al., (2002) reported that combination of organic and inorganic nutrient sources result into synergy and improved conservation and synchronization of nutrient release and crop demand, leading to increased fertiliser efficiency and higher yields.

The slight increase in maize yields following addition of $30 \mathrm{~kg} \mathrm{~N} \mathrm{ha}^{-1}$ in herbaceous legumes treatments could be attributed to additional $\mathrm{N}$ provided via the inorganic fertiliser an indication that amount of nutrients supplied by Mucuna and Crotalaria biomass did not provide adequate nutrients for maize production. Indeed, Mucuna and Crotalaria biomass did not provide adequate nutrients for maize production. Indeed, Mucuna and Crotalaria treatments provided on average $35 \mathrm{~kg} \mathrm{~N} \mathrm{ha}^{-1}$ via the incorporated prunings (Table 2). These observations agree with those of Kamidi et al. (2000) who reported that yields of plots under legumes and half recommended rates of inorganic fertiliser recorded significantly higher maize yields (Mucuna pruriens $=7.2$ ha $^{-1}$, soyabeans $=6.9 \mathrm{t} \mathrm{ha}^{-1}$, Crotaralia ochroleuca $=$ $7.4 \mathrm{tha}^{-1}$, cowpeas $=7.1 \mathrm{tha}^{1}$ and dolichos $=6.6$ $\mathrm{t} \mathrm{ha}^{-1}$ ) than the obtained from farmer practice (4.8 t ha-1). Hougnanda et al. (2001) and Kaizzi et al. (2002) also found that maize yields were nearly doubled where Mucuna was combined with fertiliser and noted that there was evidence of fertiliser being used more efficiently when combined with Mucuna than when used alone.

One of the major reasons advanced for low maize yields in herbaceous legumes treatments was low biomass production consequently contributing low amounts of $\mathrm{N}$. This corroborates finding of Baijukya (2004) and Kaizzi et al. (2006) who obtained reduced maize yields in Mucuna intercropping treatments and attributed it to low biomass production. However, the observed increases in maize yield with application of herbaceous legumes compared with the control demonstrate that legumes could make a significant contribution to crop production. Farmers would therefore benefit by incorporating these legumes in the farming systems as an option to their subsistence farming systems where farmers crop their farms without any inputs. The results further indicate that application of mineral fertiliser can be reduced if herbaceous legumes are applied on the farms. Similar results have been reported in the Kenyan highlands (Niang, 2002), in the humid areas of Uganda (Wortmann et al., 1994; Kaizzi et al., 2006), in Tanzania (Kalumuna et al., 2001; Baijukya, 2004) and in moist savanna region of West Africa (Sanginga et al., 2002).

The good performances from farmers innovated technologies where they modified the treatments and combined different organic materials could be due to increased amount of nutrients supplied via the applied materials as well as soil moisture retention by the organic materials. This is an indication that the farmers' modified technologies could be effective in improving yields. Modifications of agricultural technologies have similarly been reported by other authors (Adesina et al., 1999; Pisanelli et al., 2000; Obonyo and Franzel, 2005). Adesina et al. (1999) argue that farmers make modifications to fit their managerial and production systems. 
Other observations show that farmers do not usually adopt technologies as a package but adopt certain principles of the package while modifying particular components or management inputs. These modifications could lead to a final technological package for farmers that is adopted as it technically feasible, profitable and acceptable to farmers (Fanzel et al., 2002).

The main reason advanced by farmers for mixing the materials was that they lacked adequate materials (biomass) for incorporation and that they already knew that their soil was low in soil fertility and thus, needed large amounts of biomass. For example, farmers indicated that they added manure or Tithonia to the legumes so that the legumes would grow vigorously and provide a lot of biomass for applying into the soil during the following seasons. This is important, as the amount of plant nutrients supplied via organic materials is highly dependant on the quantity of the organic materials applied (Mathews et al., 1992). Due to lack of enough biomass for applying into the soil, mixing of the different organic materials could therefore be an important approach for improving soil fertility in these smallholder farms.

The higher maize yields from on-station experiment than the on-farm trials were probably due to on-station plots having higher soil fertility status than plots at the farms. From the characterisation data soil $\mathrm{C}$ and $\mathrm{N}$ in soils sampled from the farms was 0.73 and $0.16 \%$, respectively, while it was $1.78 \%$ and $0.24 \%$ in soils sampled from on-station experiment. Another possible explanation for the higher yields from on-station treatments compared to on-farm is better management/agronomic practices at the onstation than on the farms.

The low variability in Type 2 on-farm trials than Type 3 trial among the treatments was attributed to some control in the Type 2 trial (researcher designed, farmer managed) where the same maize variety and fertilisers were used on all farms, while Type 3 farmers worked independently and used many different types of fertilisers. Also, the higher variability in on-farm trials than on-station trial could be due to inherent variability within each farm and the differences in the management of each farm in terms of quality and amount of inputs applied. For instance, the cattle manure applied in each farm could have varied in quality depending on the feed stuff, storage and decomposition duration. Probert et al. (1995) reported that though manure is a common soil fertility resource among farmers it has been found to be variable depending on the animal, storage and handling of the manure. In the central highlands of Kenya, Lekasi et al. (2000) and Kimani et al. (2004) found high variability in the chemical composition of farm yard manures notably organic, ligin, polyphenol, organic $\mathrm{C}$, total $\mathrm{N}$ and $\mathrm{C}: \mathrm{N}$ ratio and this influenced maize yield response and nitrogen mineralisation. In addition, variability in yield especially in the Calliandra and Leucaena treatments could have been due to farmers applying varying quantities of prunings.

\section{CONCLUSION AND RECOMMENDATIONS}

At the on-station trial sole application of the organic materials at $60 \mathrm{~kg} \mathrm{~N} \mathrm{ha}^{-1}$ and combined application of organic materials (30 kg N ha ${ }^{-1}$ ) and inorganic fertiliser ( $30 \mathrm{~kg} \mathrm{~N} \mathrm{ha}^{-1}$ ) gave similar maize yields. However, these treatments gave significantly $(\mathrm{P}<0.05)$ higher yields than the recommended rate of inorganic fertiliser, indication that organic materials improved nutrient use efficiency from inorganic fertiliser. Overall conclusion is that biomass transfer technologies involving Calliandra, Leucaena and Tithonia applied solely or in combination with inorganic fertiliser at $60 \mathrm{~kg} \mathrm{~N} \mathrm{ha}^{-1}$ could be used as nutrient sources and can meet $\mathrm{N}$ requirement for maize in smallholder farming systems maintaining maize yields at 4 to $6 \mathrm{t} \mathrm{ha}^{-1}$.

Though herbaceous legumes yielded the lowest maize yields among the organic resources tested in this study, the observed increase in maize yield with application of herbaceous legumes compared with the control demonstrate that legumes make a significant contribution to crop production. Farmers would therefore benefit by incorporating these legumes in the farming systems as an option to subsistence farming where farmers currently crop their farms without any inputs. The results further indicate that maize yields above the control treatment when 
supplemented with inorganic fertiliser and application of mineral fertiliser can be reduced if herbaceous legumes are applied.

Use of manure and Tithonia alone or combined with fertiliser was most effective in increasing maize yields at the farm level and their use should be promoted. However, the yield gap between the on station and on farm trials is an indication that there exists a potential of increasing yields at the farm level through use of the tested inputs. There is therefore need to determine factors that cause the yield gap as this would help provide recommendations for maximizing production.

High variability in yields among the farms is of concern especially in farms where very low maize yields were recorded. Differences in the management are the most likely factors for the large variability and there is need to analyse the specific causes of variability. These will in turn explain yield variation among the farmers and help diagnose production constraints at the farm level that limit performance of improved technologies.

Lastly, this study has shown how farmers are likely to modify introduced agricultural technologies to fit their own circumstances. It is advisable that researchers remain open minded when evaluating technologies with farmers and analyze what farmers do rather that criticise when they change what has been introduced. As shown in this study the changes adopted by farmers might yield more benefits with potential for sustainability they fit within the existing farmers' environment. In this regard there is need to validate farmer's innovations and look for ways of improving them.

\section{ACKNOWLEDEMENT}

This work was supported by the Rockefeller Foundation and the Bentley Fellowship. We would also like to acknowledge the contributions of collaborators from Kenya Forestry Research Institute (KEFRI), Kenya Agricultural Research Institute (KARI), World Agroforestry Centre (WAC) and Kenyatta University (KU). We are grateful to all the farmers who participate in this work.

\section{REFERENCES}

Adensina, A.A., Coulibaly, D., Manyong, V.M., Sanginga, P.C., Mbila, D. Chianu, J. and Kamleu, G. 1999. Policy shifts and adoption of alley farming in West and Central Africa. IITA and Meg Communication, Ibadan, Nigeria.

Anderson, J.M. and Ingram, J.S.L. 1993. Tropical Soil Biology and Fertility: A Handbook of Methods. CAB International, Wallingford, UK.

Baijukya, F.P. 2004. Adapting to change in banana-based farming systems of northwest Tanzania: The potential role of herbaceous legumes. Ph.D. Thesis, Wageningen University, Wageningen, The Netherlands.

Bationo, A., Kimetu, J. Ikeera, S., Kimani, S., Mugendi, D., Odendo, M., Silver, M., Swift, M.J,. and Sanging, N. 2004. The African Network for soil biology and fertility: New challenges and opportunities. In: Managing Nutrient Cycles to Sustain Soil Fertility in Sub-Saharan Africa. Bationo, A. (Ed.). pp 123. Academy Science Publishers and Tropical Soil Biology and Fertility Institute of CIAT, Nairobi, Kenya.

Cadisch, G.., Handayanto, E., Malama, C., Seyni, F. and Giller, K.E. 1998. N recovery from legume prunings and pruning effects are governed by the residue quality. Plant and Soil 205: 124-134.

Dudal, R. and Roy, R. 1995. Integrated Nutrition Systems. Report of an expert consultation held in Rome Italy, 13-15 Dec. 1993. FAO Fertiliser and Plant Nutrition Bulletin.

Esilaba, A.O, Byalebek, J.B., Delve, R.J., Okalebo, J.R., Senyange, D. Mbalule, M. and Ssali, H. 2005. On farm testing of integrated nutrient management strategies in eastern Uganda. Agricultural Systems 86: 144-165.

Franzel, S., Scherr, S.J., Coe, R., Cooper, P.J.M. and Place, F. 2002. Methods for assessing agroforestry adoption potential. In: Trees on the Farm: Assessing the Adoption Potential of Agroforestry Practices in Africa. Franzel, S. and Sherr, S.J. (Eds.), pp. 11-36. CAB International, Wallingford, UK. 
Gachengo, C.N., Palm, C.A., Jama. B. and Othieno, C. 1999. Tithonia and Senna green manures and inorganic fertilisers as phosphorous sources for maize in western Kenya. Agroforestry systems 44:21-36.

Gachimbi, L. N., De Jager A., Van Kuelen H., Thuanira E.G. and Nandwa, S.M. 2004. Participatory diagnosis of soil nutrient depletion in semi-arid areas of Kenya. Managing Africa's Soils No. 26 IEED.

Ganunga, T., Terokun, O. and Kumwenda, J.D. 1998. Tithonia diversifolia: An organic source of nitrogen and phosphorous for maize in Malawi. In: Grain Legumes and Green Manures for Soil Fertility in Southern Africa: Taking Stock of Progress. Waddington SR (Ed.), pp. 191-194. Proceedings of a conference (8-11 October, 2002) Leopard Rock Hotel, Vumba, Zimbabwe. Soil Fertility Network and CIMMYT Zimbabwe, Harare, Zimbabwe.

Genstat, 2005. Genstat Release 8.1 for Windows. Lawes Agricultural trust, Rothamstead Experimental Station, UK.

GOK, 2001. Government of Kenya (2001). The 1999 Kenya National Census Results. Ministry of Home Affairs, Nairobi, Kenya.

Goyale, S. Mishra, M.M., Hooda, I.S. and Singh, R. 1992. Organic matter-microbial biomass relationships in field experiments under tropical conditions: Effects of organic fertilization and organic amendments. Soil Biology and Biochemistry 23: 83-88.

Hougnandan, P., Sanginga N., Okogun, A., Vanlauwe B. and Cleamput, O.V. 2000. Response of Mucuna to symbiotic nitrogen fixation following inoculation in farmers' fields in the derive savanna of Benin. Biology and Fertility of Soils 30:558-565.

Iwuafor, E.N.O., Aihou, K., Vanlauwe, B., Diels, J. Sanginga, N., Lyasse, O, Decekers and Merkx, R. 2002. On-farm evaluation of the contribution of sole and mixed application of organic and urea to maize production in the savannah. In: Integrated Nutrient Management in Sub-Saharan Africa: from Concept to Practice. Vanlauwe, B., Diels, N., Sanginga, N. and Merkx, R. (Eds.), pp. 185197. CAB International, Wallingford, UK.
Jaetzold, R., and Schmidit, H. 1993. Farm Management Handbook of Kenya. Natural Conditions and Far, Information. Vol. II/C. East Kenya Ministry of Agriculture, Kenya.

Jiri, O. and Waddington, S.R. 1998. Leaf prunings from two species of tithonia raise maize grain yield in Zimbabwe, but take a lot of labour. Newsletter of Soil Fert. NE, Harare, Zimbabwe. Target 16: 4-5.

Kaizzi, C.K., Charles, S. and Wortmann, B. 2002. Plant materials for soil fertility management. Agronomy Journal 93: 929-935.

Kaizzi, C.K., Ssali, H. and Vlek, P.L.G. 2006. Differential use and benefits of velvet bean (Mucuna pruriens Var. utilis) and N Fertiliser in maize production in contrasting agroecological zones of East Uganda. Agricultural Systems 88:44-60.

Kalumuna, M.C., Mtakwa, P.W. and Rwehumbizwa, F.B.R. 2001. Influence of cover crops grown in short rains on soil moisture content, soil mineral $\mathrm{N}$ and maize yields in the subsequent long rains season. In: Soil Science Research and Technologies: Foundation for Sustainable Food Security. Msaky, J.J.T., Msumali, G.P. and Rwehumbizwa, F.B.R. (Eds.), pp. 78-95. Proceedings of the $19^{\text {th }}$ Soil Science Society of East Africa (SSSEA), Moshi, Tanzania.

Kamidi, M., Gitaru. F., Osore, P. and Cheruiyot. D. 2000. Effect of green manure legumes on the yield of maize and beans in Matunda farm. Tranzoia district. Legume Research Network Project Newsletter, Issue No. 4.

Kihanda, F.M. 1996. The role of farmyard manure in improving maize production in the subhumid highlands of cental Kenya. PhD thesis. The University of Reading. UK.

Kimani, S.K., Macharia, J.M., Gachengo, C., Palm, C.A. and Delve, R.J. 2004. Maize production on the central highlands of Kenya using cattle manures combines with modest amounts of mineral fertiliser. Uganda Journal of Agricultural Sciences 9:480-490.

Kimetu, J.M., Mugendi, D.N., Palm, C.A. Mutuo, P.K. Gachengo, C.N., Bationo, A. Nandwa, S. and Kungu, J. 2004. Nitrogen fertiliser equivalencies by organics of differing 
quantity and optimum combinations with organic nitrogen source in central Kenya. Nutrient Cycling in Agroecosystems 68: 127 135.

Lekasi, J.K. Tanner, J.C., Kimani, S.K. and Harris, P.J.C. 2000. Effect of the manure on maize productivity under field conditions in a central Kenya highland Nitisol. In: Collaborative and Participatory Research for Sustainably Improved Livelihoods. Mukisira E.A., Kiriro, F.H., Wamuongo, J.W., Wamae, L. W., Muriithi, F.M. and Wasike, W. (Eds.), pp. 123131. Proceedings of the $7^{\text {th }}$ Biennial Scientific Conference, Kenya Agricultural Research Institute (KARI) Nairobi, Kenya.

Mugendi, D.N., Nair, P.K.R., Mugwe, J.N., O’Neill, M.K. and Woomer, P. 1999. Alley cropping of maize with calliandra and leucaena in the subhumid highlands of Kenya. Part 1: Soil fertility changes and maize yield. Agroforestry systems 46:39-50.

Murwira, H.K., Mutuo, P.K., Nhamo, N. Marandu, A.E., Rabeson, R., Mwale, M. and Palm, C.A. 2002. Fetiliser equivalency values of organic materials of different quality In: Vanlauwe B, Diels, J, Sanging, N. and Merckx, R. (Eds.). In: Integrated Nutrient Management in SubSaharan Africa: From Concept to Practice. Vanlauwe, B., Diels, N., Sanginga, N. and Merkx, R. (Eds.), pp. 113-152. CAB International, Wallingford, UK.

Mutsaers, H.J.W., Weber, G.K., Walker, O, and Fischer, M. 1997. A Guide for On-farm Experimentation. IITA/CT/ISNAR.

Nandwa, S.M. 2003. Soil organic carbon (SOC) management for sustainable productivity of cropping and agroforestry systems in Eastern and Southern Africa. Nutrient Cycling in Agroecosystems 61: 143-158.

Niang, A. 2002. On-farm testing of organic and inorganic phosphorous source on maize in Western Kenya. In: The Biology and Fertility of Tropical Soils. TSBF Annual Report, Nairobi, Kenya.

Obonyo, E. and Franzel, S. 2005. Biomass technology transfer experiences in Western Kenya. In: Recent advances in forestry research and technology development for sustainable forest management. Muchiri, M.N., Kamondo, B., Tuwei, P. and Wanjiku, J.
(Eds), pp. 273-281. Proceddings of the $2^{\text {nd }}$ KEFRI Scientific conference. Kenya Forestry Research Institute (KEFRI), Muguga, Kenya.

Odhiambo, M.O. 1994. The Kenya maize subsector. A rapid approach with emphasis on market information needs and extension issues. Market information systems report. No. 94-03. CIMMYT, Nairobi, Kenya.

Okalebo, J.R., Gathua, K.W. and Woomer, P.L. 2002. Laboratory Methods of Soil and Plant Analysis: A Working Manual. $2^{\text {nd }}$ Edition. TSBF-CIAT and SACRED Africa, Nairobi, Kenya.

Okalebo, J.R., Palm. C.A., Lekasi, J.K., Nandwa, S.M., Othieno, C.O., Waigwa, M. and Ndungu, K.W. 2003. Use of organic and inorganic resources to increase maize yields in some Kenyan soils: A five year experience. In: Proceedings of the $8^{\text {th }}$ meeting of the African Network of Tropical (AfNET) of Soil Biology and Fertility Research. Bationo A and Swift MJ (Eds.). Nairobi, Kenya.

Okoko, E.N.K., Makini. F. and Mureithi, J.G. 2003. Effect of organic and inorganic fertilisers on maize and traditional vegetable yields in Kissi highlands. East Africa Agriculture and Forestry Journal 69(1): 89-98.

Parkinson, J.A. and Allen, S.E. 1975. A wet oxidation procedure suitable for the determination of nitrogen and mineral nutrients in biological materials. Communications in Soil Science and Plant Analysis 6:1-11.

Pingali, P.L. 2001. World Maize: Facts and Trends. Meeting World Maize Needs: Technological Opportunities and Priorities for the Public Sector. CIMMYT 1999 - 2000. CIMMYT. Mexico. D.F.

Pisanelli, A., Franzel, S., Dewolf, J., Rommelse, R. and Pooke, J. 2000. Adoption of improved tree fallows in Western Kenya. Farmer practices, knowledge and perception. International Centre for Research in Agroforestry (ICRAF) (WAC), Nairobi, Kenya.

Probert, M.E. Okalebo, J.R. and Jones, R.K. 1995. The use of manure on smallholder farms in semi-arid eastern Kenya. Experimental Agriculture 31:371-381. 
Sanchez, P.A. and Jama, B.A. 2002. Soil fertility replenishment takes off in East and southern Africa. In: Integrated Nutrient Management in Sub-Saharan Africa: from Concept to Practice. Vanlauwe, B., Diels, N., Sanginga, N. and Merkx, R. (Eds.), pp. 23 - 46. CAB International, Wallingford, UK.

Sanginga, N., Lyasse, O., Merckx, R. and Deckers J. 2002. Maize yield as affected by organic inputs and urea in the West-African most Savannah. Agronomy Journal 93:1191-1199.

Smaling, E.M.A., Nandwa, S.M. and Janssen, B.H. 1997. Soil fertility is at stake. In: Replenishing Soil Fertility in Africa: An Investment in Natural Resource Capital. Buresh R.J., Sanchez, P.A. and Callhoun, F. (Eds.), pp. 4761. Soil Science Society of America Special (SSSA) Publication 51: Soil Science Society of America, Madison WI, USA.
Stern, R.D., Coe, R., Allan, E.F. and Dale, I.C. 2004. Good statistical practice for natural resource research. CAB International, Wallingford, UK.

Tian, G. and Kang, B.T. 1998. Effects of soil fertility and fertiliser application on biomass and chemical composition of leguminous cover crops. Nutrient Cycling 51:231-238.

Vanlauwe, B.J., Diels K., Aihou., Iwuafor, I.N.O., Lyasse, O., Sanginga, N. and Merckx, R. 2002. Direct interactions between $\mathrm{N}$ fertiliser and Organic Matter: Evidence from trials with $15 \mathrm{~N}$ labelled fertiliser. In: Integrated Nutrient Management in Sub-Saharan Africa: From Concept to Practice. Vanlauwe, B., Diels, N., Sanginga, N. and Merkx, R. (Eds.), pp. 173184. CAB International Wallingford, Oxon, UK. 